\title{
Comparison of Techniques for Detection of Barley Yellow Dwarf Virus-PAV-IL
}

Antonia R. Figueira, Dep. Fitopatologia, UFLA/Lavras-MG.Brazil, Leslie L. Domier, USDA-ARS Crop Protection Unit, University of Illinois, Urbana, and Cleora J. D'Arcy, Department of Plant Pathology, University of Illinois, Urbana

\begin{abstract}
Figueira, A. R., Domier, L. L., and D'Arcy, C. J. 1997. Comparison of techniques for detection of barley yellow dwarf virus-PAV-IL. Plant Dis. 81:1236-1240.

Detection of barley yellow dwarf virus (BYDV)-PAV-IL by an improved nucleic acid hybridization technique, using a nonradioactive probe with chromogenic and chemiluminescent substrates, was compared with detection by polymerase chain reaction (PCR), double antibody sandwich enzyme-linked immunosorbent assay (DAS-ELISA) with polyclonal antibodies, and triple antibody sandwich ELISA with polyclonal and monoclonal antibodies. Each method was used to detect purified virus and virus in sap extracts from infected oat leaves. The detection limits for both ELISA procedures were $1 \mathrm{ng}$ of purified BYDV-PAV-IL and the equivalent of 78 ng of infected tissue. Nucleic acid hybridization with either chemiluminescent or chromogenic substrates also detected as little as $1 \mathrm{ng}$ of purified BYDV-PAV-IL, but it was slightly more sensitive at detecting virus in tissue extracts ( $25 \mathrm{ng}$ of infected tissue). The most sensitive detection technique was PCR amplification, which could detect as little as $0.1 \mathrm{pg}$ of RNA extracted from purified virus and detected viral RNA in the equivalent of $0.5 \mathrm{pg}$ of infected leaf tissue.
\end{abstract}

Additional keywords: dot blot, luteovirus

Barley yellow dwarf viruses (BYDVs) are found worldwide in 54 countries from seven continents (18). The five strains of BYDV that have been detected in North America are divided into two subgroups based on biological and genomic properties (12,28). Strains related to BYDV-PAV, which are typically among the more damaging of the BYDV strains, have been found to be the most prevalent in more than $50 \%$ of the countries surveyed.

BYDVs are phloem-limited and are present at low concentrations in extracts of infected tissues (7). The sensitivity of a detection technique is therefore important for efficient detection of these viruses in field samples. Enzyme-linked immunosorbent assays (ELISA) are increasingly used to detect BYDVs, but other techniques, such as polymerase chain reaction (PCR) and nucleic acid hybridization, have been reported to be more sensitive and capable of distinguishing the different virus strains $(2,11,14)$. Even though nucleic acid hybridization is considered a powerful technique for the detection of plant viruses $(11,14,16)$, the hazards of using radioactive probes and the problems of nonspecific hybridization of probes with healthy samples, especially when crude

Corresponding author: A. R. Figueira

E-mail: ESAL@BRUFMG.BITNET

Accepted for publication 6 June 1997.

Publication no. D-1997-0902-01R

(C) 1997 The American Phytopathological Society extracts are tested, have discouraged its widespread use.

In this paper, we present a direct comparison of the sensitivity of an improved nucleic acid hybridization technique using a nonradioactive probe with the sensitivities of ELISA and PCR for detecting BYDV-PAV-IL as purified virus or in extracts from infected plants. Variations of the techniques tested include use of chromogenic or chemiluminescent detection systems in the hybridization assay, double antibody sandwich (DAS) ELISA with polyclonal antibodies for virus capture and detection, and triple antibody sandwich (TAS) ELISA with monoclonal antibodies for virus detection.

\section{MATERIALS AND METHODS}

Virus preparation. The BYDV-PAV-IL strain and its aphid vector, Rhopalosiphum padi L., were maintained in Hudson barley (Hordeum vulgare L.) grown in the greenhouse. Virus was purified from Coast Black oats by the method described by D'Arcy et al. (9).

DAS- and TAS-ELISA. Leaf samples were collected from infested and noninfested greenhouse-grown Coast Black oats (Avena sativa L.) and tested fresh or after storage at $-80^{\circ} \mathrm{C}$ for 1 to 2 months. For sap extractions, $0.5 \mathrm{~g}$ of leaf tissue was ground in liquid nitrogen, and the powder was resuspended in $10 \mathrm{ml}$ of phosphate-buffered saline (PBS), $\mathrm{pH}$ 7.4. Leaf extracts were diluted $1: 20$ to $1: 2,560$ times and tested by DAS-ELISA and TAS-ELISA, as described by D'Arcy et al. (8), with the modification that alkaline phosphatase conjugates were incubated $2 \mathrm{~h}$ at $37^{\circ} \mathrm{C}$ instead of overnight. Samples with absorbance at $405 \mathrm{~nm}$ greater than twice the mean absorbance of 24 control wells were considered positive.

Dot blot hybridization. The cDNA used for nucleic acid hybridization was pPAV410, which represents a nearly fulllength copy of BYDV-PAV-IL genome (11). Hybridization probes were prepared by random primer labeling and/or PCR amplification using either Biotin-14-dATP (Life Technologies, Gaithersburg, MD) or Biotin-14-dCTP (Tropix, Bedford, MA).

To prepare the samples for dot blot hybridization, $1 \mathrm{~g}$ of leaf was ground in liquid nitrogen and resuspended in $5 \mathrm{ml}$ of PBS containing 1 to $3 \mathrm{mg}$ of $\mathrm{Mg}$-bentonite prepared by the method of Dunn and Hitchborn (10), with the bentonite-buffer mixture shaken for at least $3 \mathrm{~h}$ in the first and second steps before centrifugation. Each new Mg-bentonite preparation was tested in order to determine the optimal concentration of $\mathrm{Mg}$-bentonite for extraction.

The leaf extract was stirred for $15 \mathrm{~min}$ at room temperature (RT) and centrifuged for $10 \mathrm{~min}$ at $14,000 \mathrm{rpm}$. One volume of supernatant was mixed with 3 volumes of disruption buffer $(33 \%$ formamide, $12 \%$ formaldehyde, $20 \mathrm{mM} 3$-[N-morpholino]propane-sulfonic acid, $1 \mathrm{mM}$ NaEDTA, $\mathrm{pH}$ 7.0), incubated for $5 \mathrm{~min}$ at $65^{\circ} \mathrm{C}$, and cooled on ice for $2 \mathrm{~min}$. Four volumes of $0.3 \mathrm{M}$ sodium citrate buffer, $\mathrm{pH} 7$, and 3.0 $\mathrm{M} \mathrm{NaCl}(20 \times \mathrm{SSC})$ were added, and the mixture was centrifuged at $14,000 \mathrm{rpm}$ for $10 \mathrm{~min}$. The supernatant was applied through a Hybri-Dot manifold (GibcoBRL, Life Technologies, Gaithersburg, MD) to a positively charged nylon membrane (Amersham, Arlington Heights, IL) for chemiluminescent detection and to a nitrocellulose membrane for chromogenic detection, both prewetted in $10 \times$ SSC. The volumes applied ranged from 200 to $1 \mu \mathrm{l}$ in each well. Volumes higher than $200 \mu \mathrm{l}$ were applied to the first membranes prepared, but the membranes became plugged and the chromogenic and chemiluminescent signals were not clear. For sample volumes below $10 \mu \mathrm{l}$, the volume was adjusted to $10 \mu \mathrm{l}$ with $10 \times \mathrm{SSC}$ to produce a larger spot on the membrane. After sample application, wells were washed with $100 \mu \mathrm{l}$ of $10 \times \mathrm{SSC}$, and the membranes were allowed to dry for $10 \mathrm{~min}$ in a vacuum oven at $80^{\circ} \mathrm{C}$ and were UV crosslinked with a Stratagene Stratalinker. 
The prehybridization/hybridization solution contained $5 \times$ SSC, $0.1 \%$ N-lauroylsarcosine, $0.1 \%$ I-block (Tropix), and $0.02 \%$ sodium dodecyl sulfate (SDS). Membranes were prehybridized for $30 \mathrm{~min}$ at $68^{\circ} \mathrm{C}$ and hybridized overnight with $4 \mathrm{ng}$ of probe per $\mathrm{ml}$ of hybridization solution in a roller bottle. Nylon membranes were washed three times with PBS, $0.5 \%$ SDS (twice for $5 \mathrm{~min}$ at RT and once for $30 \mathrm{~min}$ at $60^{\circ} \mathrm{C}$ ), and finally for $5 \mathrm{~min}$ at RT with $2 \times$ PBS. The procedure for chemiluminescent detection was that of Martin and Olesen (21).

Nitrocellulose membranes were washed three times after hybridization with $0.1 \%$ SSC, $1 \%$ SDS (twice for $5 \mathrm{~min}$ at RT and once for $30 \mathrm{~min}$ at $60^{\circ} \mathrm{C}$ ). The membranes were then washed once in $2 \times$ SSC for 5 min at RT and incubated with $3 \%$ BSA in $0.1 \mathrm{M}$ Tris base, $150 \mathrm{mM} \mathrm{NaCl}$, and $0.05 \%$ Tween 20, pH 7.5, (PBS-Tween) for $1 \mathrm{~h}$ at $60^{\circ} \mathrm{C}$. The membranes were incubated with strepavidin alkaline phosphatase (BRL, Zymed, or Tropix) for $15 \mathrm{~min}$ and washed twice in TBS-Tween for $15 \mathrm{~min}$ at RT. The chromogenic signals were detected by incubation of membranes with chromogenic substrate BCIP/NBT (4-bromo-4chloro-3-indolyl phosphate/nitro blue tetrazolium) for approximately $2 \mathrm{~h}$.

PCR amplification. RNA was extracted from purified BYDV-PAV-IL as described by Gibson et al. (13). Nucleic acids were extracted from infected and noninfected plants by grinding $0.5 \mathrm{~g}$ of leaf tissue in liquid nitrogen and resuspending the resulting powder in $5 \mathrm{ml}$ of $0.1 \mathrm{M}$ glycine buffer, $\mathrm{pH} 9.5,0.1 \mathrm{M} \mathrm{NaCl}$, and $10 \mathrm{mM}$ EDTA. Purification of viral RNA from the plant extract and transcription of RNA from purified virus and plant extract were by the methods of Robertson et al. (23), with the modification that primers PAV3' and 6.7 $\mathrm{kBam}$ were used for PCR amplifications instead of $\mathrm{Lu}_{1}$ and $\mathrm{Lu}_{4}$. PCR products were analyzed by electrophoresis of $10 \mu \mathrm{l}$ of the PCR reaction mixture on $1.4 \%$ agarose gels using Tris-acetate buffer, $\mathrm{pH} 8.0$ (24).

\section{RESULTS}

The sensitivities of the two serological methods tested-DAS-ELISA and TAS ELISA-for detection of BYDV-PAV-IL were similar. With either method, it was possible to detect as little as $1 \mathrm{ng}$ of purified virus and virus in leaf extracts diluted as far as 1:640, which was equivalent to 78 ng of infected leaf tissue (Table 1). Besides having similar sensitivity, TAS presented lower absorbance variation than DASELISA technique (Figs. 1 and 2).

The use of Mg-bentonite in the hybridization technique eliminated nonspecific hybridization of the probe with healthy plant samples and increased its sensitivity. The chemiluminescent and chromogenic substrates had very similar sensitivities for detection of BYDV-PAV-IL. The smallest quantity of purified virus that could be detected varied from 0.5 to $2 \mathrm{ng}$, and it was possible to detect virus in extracts equivalent to between 25 and $50 \mathrm{ng}$ of infected leaf tissue. Most tests made it possible to

detect $1 \mathrm{ng}$ of purified virus and virus in 1 $\mu \mathrm{l}$ of plant extract, which was equivalent to $25 \mathrm{ng}$ of infected leaf tissue (Table 1 and Fig. 3).

Table 1. Comparison of the sensitivities of detection techniques for barley yellow dwarf virus (BYDV)-PAV-IL

\begin{tabular}{lcc}
\hline & \multicolumn{2}{c}{ Detection endpoint } \\
\cline { 2 - 3 } Technique & Infected tissue & Purified virus \\
\hline DAS-ELISA ${ }^{\mathrm{a}}$ & $78 \mathrm{ng}$ & $1 \mathrm{ng}$ \\
TAS-ELISA $^{\mathrm{a}}$ & $78 \mathrm{ng}$ & $1 \mathrm{ng}$ \\
Hybridization-chemiluminescent $_{\text {Hybridization-chromogenic }}$ & $25 \mathrm{ng}$ & $1 \mathrm{ng}$ \\
Polymerase chain reaction & $25 \mathrm{ng}$ & $1 \mathrm{ng}$ \\
\hline
\end{tabular}

a Double antibody sandwich (DAS) enzyme-linked immunosorbent assay (ELISA); triple antibody sandwich (TAS) ELISA.

${ }^{b}$ RNA extracted from purified virus and diluted in sterile water.

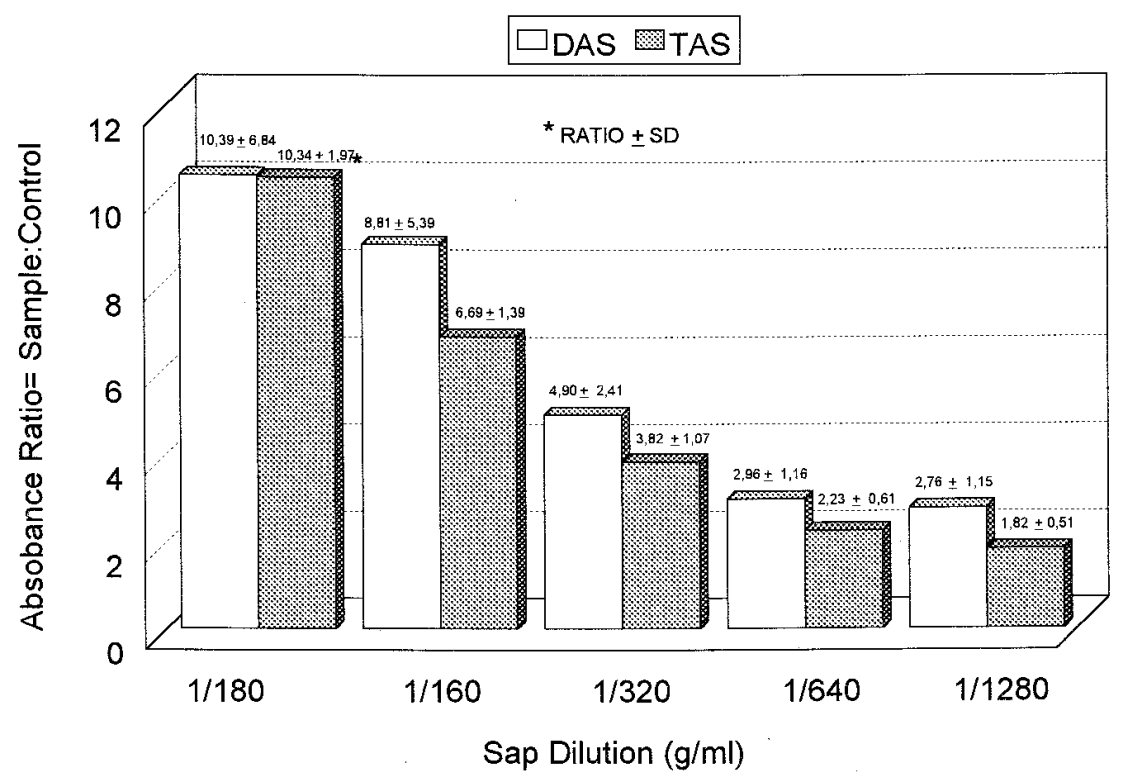

Fig. 1. Average of sample:control absorbance ratio obtained in 10 double antibody sandwich (DAS) and triple antibody sandwich (TAS) enzyme-linked immunosorbent assays (ELISA) for the detection of barley yellow dwarf virus (BYDV)-PAV-IL in infected leaf tissue.

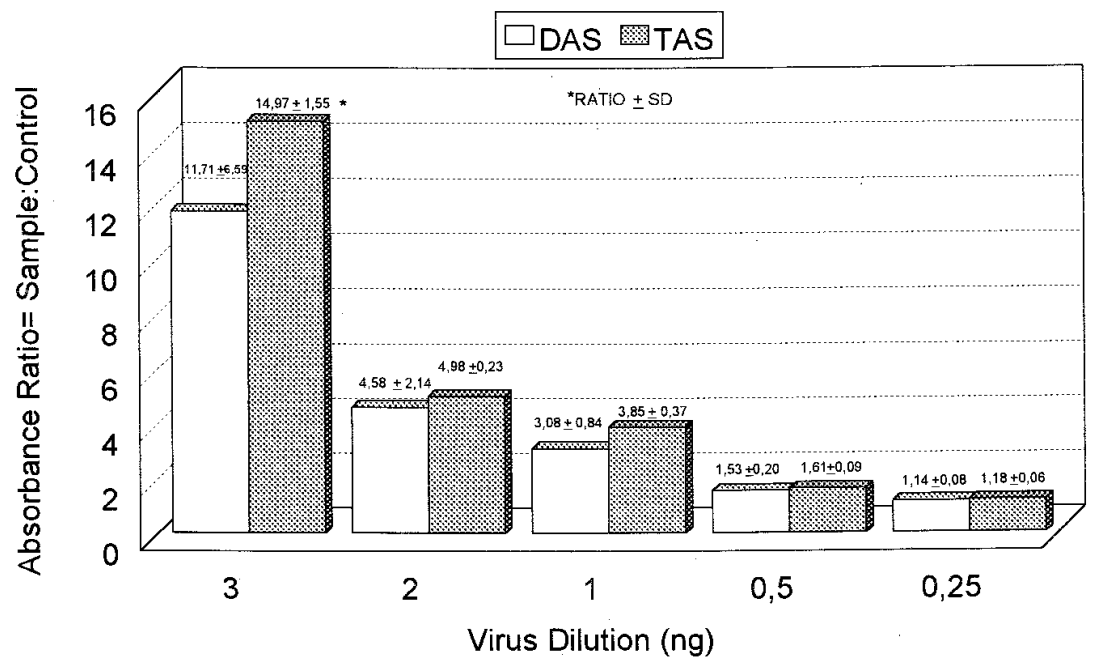

Fig. 2. Average of sample:control absorbance ratio obtained in 10 double antibody sandwich (DAS) and triple antibody sandwich (TAS) enzyme-linked immunosorbent assays (ELISA) for the detection of purified barley yellow dwarf virus (BYDV)-PAV-IL. 
PCR was the most sensitive detection technique tested, detecting BYDV-PAV-IL in extracts from infected leaves diluted $10^{-9}$, or the equivalent of $0.5 \mathrm{pg}$ of infected leaves. When RNA extracted from purified virus was diluted in water, PCR products could be detected in samples diluted $10^{-4}$, corresponding to $0.1 \mathrm{pg}$ of purified virus (Fig. 4).

\section{DISCUSSION}

The sensitivity of the two ELISA techniques was similar to that of the nucleic acid hybridization technique for detection of purified BYDV-PAV-IL. However, the serological techniques were less sensitive than the hybridization technique for detection of virus in infected leaf tissue, probably because plant components from the crude extracts can interfere with the ELISA techniques. Smith et al. (25), working with radioactive probes, found that dot blot hybridization had the same sensitivity as DAS-ELISA for the detection of potato leafroll virus (PLRV) in infected leaf tissue. Both techniques detected virus in plant sap diluted 1:32.

Although the sensitivities of the DASand TAS-ELISA systems for BYDV-PAVIL were similar, TAS-ELISA provided clearer results, as found previously by D'Arcy et al. (8). Results for TAS-ELISA were consistent, whereas the results obtained with DAS-ELISA sometimes were variable, especially when different coating and/or conjugate antibody preparations were used.

Higher and lower sensitivities have been reported in the literature for the detection of BYDV and other luteoviruses by ELISA techniques. D' Arcy and Hewings (6), using DAS-ELISA for the detection of three luteoviruses-BYDV, beet western yellows virus (BWYV), and soybean dwarf virus (SDV) - detected purified viruses at concentrations as low as $1.6 \mathrm{ng} / \mathrm{ml}$ (corresponding to $0.16 \mathrm{ng}$ per well). Van den Heuvel and Peters (26) compared

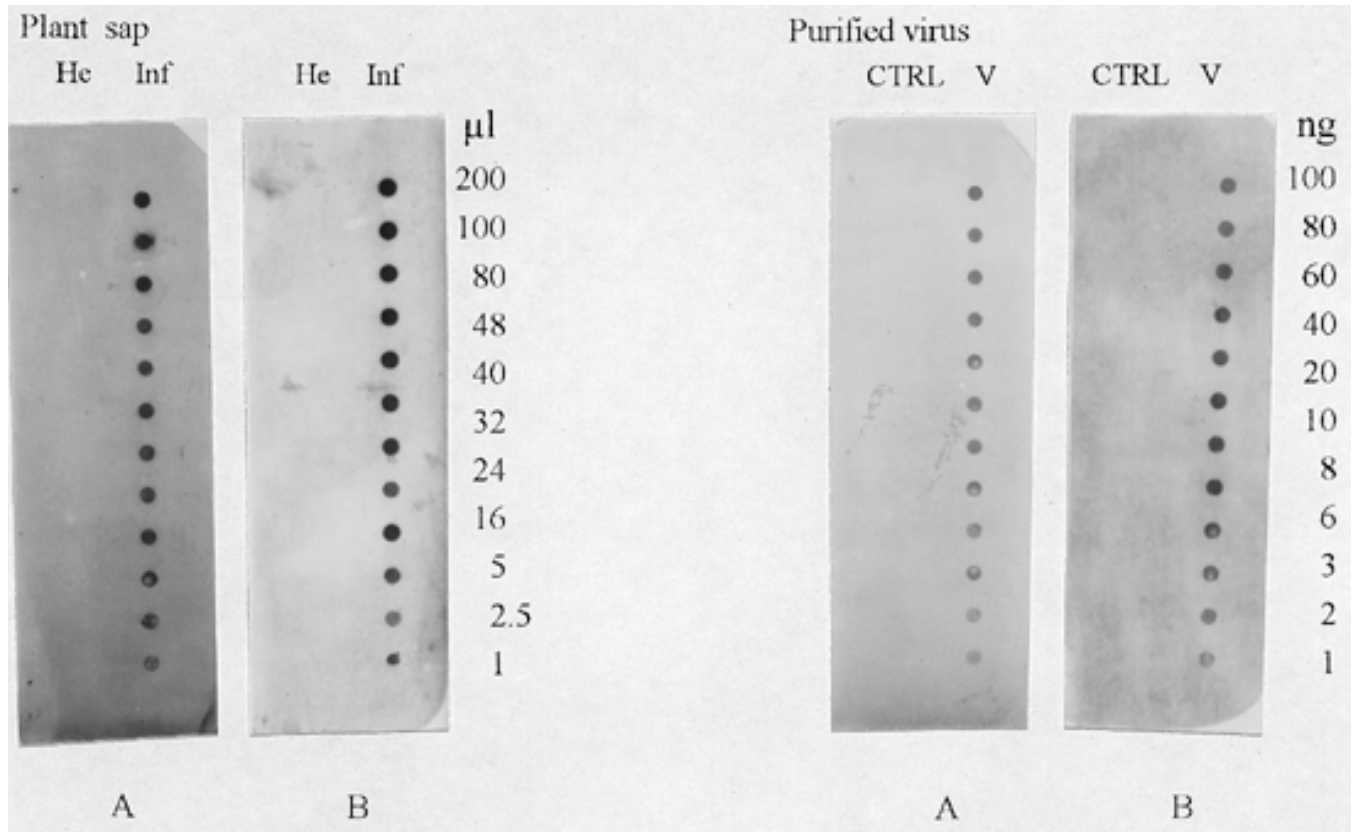

Fig. 3. Chromogenic and chemiluminescent detection of barley yellow dwarf virus (BYDV)-PAV-IL using biotinylated cDNA probes. Plant sap was denatured and applied either to (A) nitrocellulose membrane for chromogenic detection or (B) positively charged nylon membrane for chemiluminescent detection.

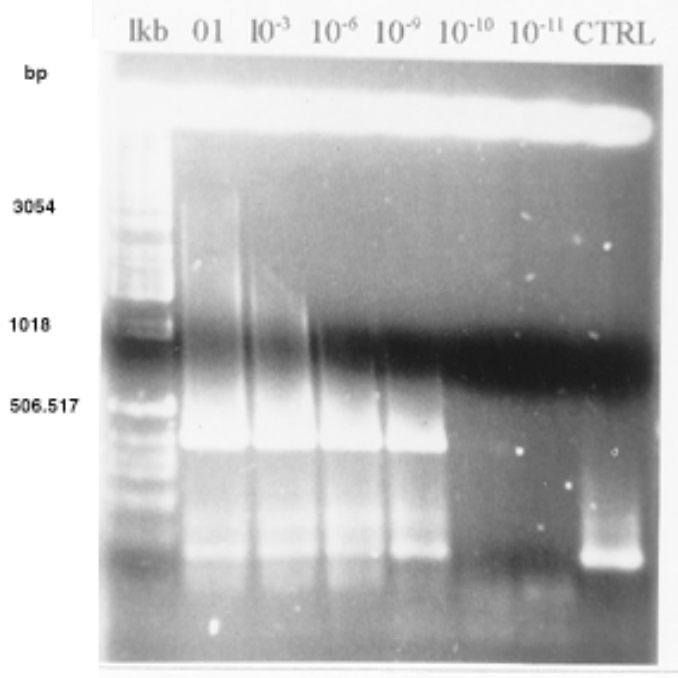

A
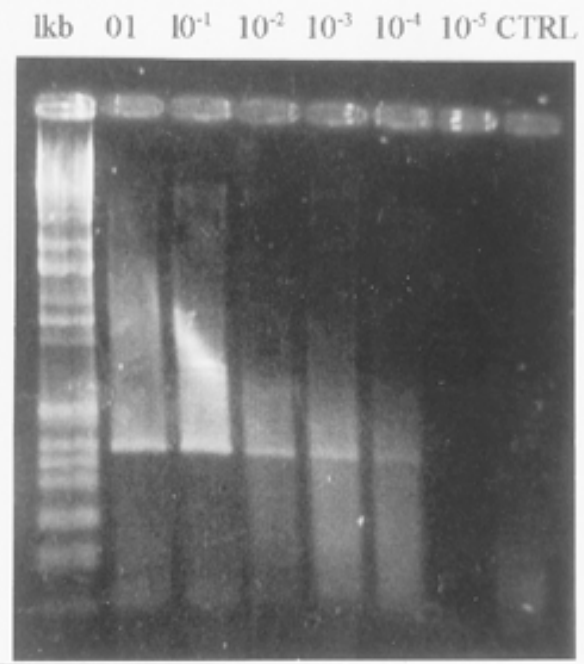

B

Fig. 4. Polymerase chain reaction (PCR) detection of barley yellow dwarf virus (BYDV)-PAV-IL RNA extracted from (A) infected plants or (B) purified virions. Products were analyzed by electrophoresis on a $1.4 \%$ agarose gel. Lane 1 contains $1 \mathrm{~kb}$ ladder size standards. 
cocktail, DAS-ELISA, and an amplification of the enzyme reaction in ELISA technique for the detection of PLRV. They could detect, respectively, $1 \mathrm{ng}, 8 \mathrm{ng}$, and 50 to $100 \mathrm{pg}$ of purified virus. Others authors found $2 \mathrm{ng}$ of virus and $200 \mathrm{ng}$ of infected leaf tissue, the limit for detection of PLRV by DAS-ELISA (1). For cherry leaf roll virus (CLRV) detection by DASELISA, the authors found the limit at 40 $\mathrm{ng}$ of purified virus and 2.5 to $1.25 \mathrm{mg}$ of infected leaf tissue (2).

Improvements in the nucleic acid hybridization technique developed in this study reduce some of the limitations cited for its use in routine virus diagnosis. The most significant improvement was the elimination of background, or nonspecific, reactions between the hybridization probe and components of the healthy plant extract $(2,19,22)$. The extraction of plant sap with PBS containing $\mathrm{Mg}$-bentonite not only eliminated this background, but also made the use of chromogenic substrate equally sensitive to use of chemiluminescent substrate for detecting BYDV-PAV-IL in infected plants. As chromogenic detection is faster, easier, and cheaper, it could become a good alternative for routine use in virus diagnosis.

Dunn and Hitchborn (10) found that Mg-bentonite absorbed ribosomes, 18S protein, and "green material" from plant extracts. Any of these could be the agent(s) responsible for nonspecific hybridization of cDNA probes, which makes it impossible to distinguish between healthy and infected plants. Indeed, the use of $\mathrm{Mg}$ bentonite is easier and takes less time than the extraction and precipitation of plant nucleic acids described previously $(4,14,22)$

The reduction of the prehybridization to 30 min shortens the time required to complete the nucleic acid hybridization protocol. In most other protocols for chemiluminescent and chromogenic detection of plant viruses, prehybridization times vary from 2 to $4 \mathrm{~h}(2,5,11,22)$. Habili et al. (14) used 4 to $16 \mathrm{~h}$ for prehybridization. In our experiments, no differences in results were observed when the prehybridization time was increased beyond $30 \mathrm{~min}$.

The sensitivity of the hybridization technique varied when alkaline phosphatase from different sources was used. Variation in detection sensitivity with different enzymes and substrates has been noted by others as well $(19,20)$. This indicates that the real sensitivity of the nucleic hybridization technique depends on the optimal ratio of enzyme to substrate. In our study, the detection limits of the hybridization assays varied from 0.5 to $2 \mathrm{ng}$ of purified virus and from 12.5 to $50 \mathrm{ng}$ of virus in infected leaf tissue.

Different sensitivities for dot blot hybridization have been found by several authors. Using nonradioactive probes, Borja and Ponz (2) detected CLRV in 160 $\mu \mathrm{g}$ of infected leaf tissue and in less than 1 ng of purified viral RNA with a chromogenic assay. They also detected virus in $30 \mu \mathrm{g}$ of infected leaf tissue and $250 \mathrm{pg}$ of purified viral RNA with a chemiluminescent assay. Using the same technique, Fouly et al. (11) detected $1 \mathrm{ng}$ of purified BYDV-PAV-IL. Radioactive probe was used by Borja and Ponz (2) to detect CLRV. They detected $26 \mathrm{ng}$ of purified virus and found that the sensitivity of nitrocellulose membrane was about eight times greater than that of nylon membrane, detecting down to $0.3 \mathrm{mg}$ of virus in infected leaf tissue.

When the chemiluminescent substrate was used with large-volume samples (320 $\mu \mathrm{l}$, data not shown) applied onto a positively charged nylon membrane, the chemiluminescent signal obtained was very light, suggesting some inhibition of hybridization. Similar inhibition was observed by Chu et al. (3) and by Borja and Ponz (2) when they applied larger amounts of samples onto a nylon membrane in chemiluminescent assays.

PCR, as reported previously by many others $(2,15,17,23,27)$, is a very sensitive technique for plant virus detection and was the most sensitive of the techniques tested in this study. PCR allowed detection of 0.1 pg of purified BYDV-PAV-IL RNA and of virus in $0.5 \mathrm{pg}$ of infected leaf tissue. When the primers $\mathrm{Lu}_{1}$ and $\mathrm{Lu}_{4}$ (23) were used, the PCR products often showed very long smears on agarose gels (data not shown), making interpretation of results difficult. The use of primers specific for the 3'-end of BYDV-PAV-IL RNA, PAV3' and $6.7 \mathrm{kBam}$, increased the sensitivity of the assay and produced more clearly defined bands.

The sensitivity of PCR for detection of plant virus can be different for different virus and plant materials, but it is always higher than other methods. Borja and Ponz (2) detected CLRV in 5 pg of infected tobacco leaves, $5 \mathrm{ng}$ of infected walnut buds, and $5 \mu \mathrm{g}$ of infected walnut twigs. Hadidi et al. (15) estimated that the theoretical minimum amount of purified PLRV RNA required for detection by RT-PCR amplification and polyacrylamide gel electrophoresis analysis was $1 \mathrm{fg}$.

Since PCR is a very sensitive technique and requires only a small quantity of infected tissue, it has been considered a useful alternative to ELISA for plant virus detection (2). The results of this study indicate that PCR certainly is the most sensitive method for detection of BYDVPAV-IL. However, the less sensitive ELISA techniques may still be better suited for work with large numbers of samples, as in routine indexing or epidemiological studies. The simplicity of the ELISA techniques, the relatively small amount of labor required, and the high quality, readily available reagents employed make their use more economical and practical when many samples need to be processed at the same time. For molecular biology research, where small quantities of material normally are processed, or for analyses of material from germplasm repositories, where it is important to detect small concentrations of contaminating virus, PCR and cDNA hybridization techniques are probably the methods of choice for plant virus detection.

\section{LITERATURE CITED}

1. Banttari, E. E., Clapper, D. L., Hu, S.-P., Daws, K. M., and Khurana, S. M. P. 1991. Rapid magnetic microsphere enzyme immunoassay for potato virus $\mathrm{X}$ and potato leafroll virus. Phytopathology 81:1039-1042.

2. Borja, M. J., and Ponz, F. 1992. An appraisal of different methods for the detection of walnut strain of cherry leafroll virus. J. Virol. Methods 36:73-83.

3. Chu, P. W. G., Waterhouse, P. M., Martin, R. R., and Gerlach, W. L. 1989. New approaches to the detection of microbial plant pathogens. Biotechnol. Genet. Eng. Rev. 7:45-110.

4. Creamer, R., and Harper, K. 1993. Detection of plant viruses using non-radioactive dot blot hybridization. (Abstr.) Phytopathology 83:1401.

5. Crespi, S., Accotto, G. P., Caciagli, P., and Gronenborn, B. 1991. Use of digoxigenin-labelled probes for detection and host-range studies of tomato yellow leaf curl geminivirus. Res. Virol. 142:283-288.

6. D'Arcy, C. J., and Hewings, A. D. 1986 Enzyme-linked immunosorbent assays for study of serological relationships and detection of three luteoviruses. Plant Pathol. 35:288-293.

7. D'Arcy, C. J., Hewings, A. D., Burnet, P. A., and Jedlinski, H. 1983. Comparative purification of two luteoviruses. Phytopathology 73:755-759.

8. D'Arcy, C. J., Hewings, A. D., and Eastman, C. E. 1992. Reliable detection of barley yellow dwarf viruses in field samples by monoclonal antibodies. Plant Dis. 76:273-276.

9. D'Arcy, C. J., Martin, R. R., and Spiegel, S. 1989. A comparative study of luteovirus purification methods. Can. J. Plant Pathol. 11:251-255.

10. Dunn, D. B., and Hitchborn, J. H. 1965. The use of bentonite in the purification of plant viruses. Virology 25:171-192.

11. Fouly, H. M., Domier, L. L., and D'Arcy, C. J. 1992. A rapid chemiluminescent detection method for barley yellow dwarf virus. J. Virol. Methods 39:291-298.

12. Francki, R. I. B., Fauquet, C. M., Knudson, D. L., and Brown, F. 1991. Pages 309-311 in: Classification and nomenclature of viruses. Springer-Verlag, Vienna.

13. Gibson, K. M., Mori, J., and Clewley, J. P. 1993. Detection of HIV-1 in serum, using reverse transcription and the polymerase chain reaction (RT-PCR). J. Virol. Methods 43:101 110 .

14. Habili, N., McInnes, J. L., and Symons, R. H 1987. Nonradioactive, photobiotin-labelled DNA probes for the routine diagnosis of barley yellow dwarf virus. J. Virol. Methods 16:225-237.

15. Hadidi, A., Montasser, M. S., Levy, L., Goth, R. W., Converse, R. H., Madkour, M. A., and Skrzeckowski, L. J. 1993. Detection of potato leafroll and strawberry mild yellow-edge luteoviruses by reverse transcription-polymerase chain reaction amplification. Plant Dis. 77:595-601.

16. Hull, R., and Al-Hakin, A. 1988. Nucleic acid hybridization in plant virus diagnosis and 
characterization. Trends Biotechnol. 6:213-218.

17. Korschineck, I., Himler, G., Sagl, R., Steinkellner, H., and Katinger, H. W. D. 1991. A PCR membrane spot assay for the detection of plum pox virus RNA in bark of infected trees. J. Virol. Methods 31:139-146.

18. Lister, R. M., and Ranieri, R. 1995. Distribution and economic importance of barley yellow dwarf. Pages 29-53 in: Barley Yellow Dwarf Virus - 40 Years of Progress. C. J. D'Arcy and P. A. Burnett, eds. American Phytopathological Society, St. Paul, MN.

19. Makkouk, K. M., Hsu, H. T., and Kumari, S. G. 1993. Detection of three plant viruses by dot-blot and tissue-blot immunoassays using chemiluminescent and chromogenic substrates. J. Phytopathol. 139:97-102.

20. Martin, C., Bresnick, L., Juo, R. R., Voyta, L. C., and Bronstein, I. 1991. Improved chemi- luminescent DNA sequencing. Biotechniques 11:110-113.

21. Martin, C. S., and Olesen, C. E. M. 1993. Improved chemiluminescent detection of biotinylated DNA on positively charged nylon membrane. Tropix Luminescence Topics 2:12.

22. Más, P., Sánchez-Navarro, J. A., SánchezPina, M. A., and Pallás, V. 1993. Chemiluminescent and colorigenic detection of cherry leaf roll virus with digoxigenin-labeled RNA probes. J. Virol. Methods 39:291-298.

23. Robertson, N. L., French, R., and Gray, S. M. 1991. Use of group-specific primers and the polymerase chain reaction for the detection and identification of luteoviruses. J. Gen. Virol. 72:1473-1477.

24. Sambrook, J., Fritsch, E. F., and Maniatis, T. A. 1989. Molecular Cloning: A Laboratory
Manual. Cold Spring Harbor Laboratory, Cold Spring Harbor, NY.

25. Smith, O. P., Damsteegt, V. D., Keller, C. J., Beck, R. J., and Hewings, A. D. 1993. Detection of potato leafroll virus in leaf and aphid extracts by dot-blot hybridization. Plant Dis. 77:1098-1102.

26. van den Heuvel, J. F. J. M., and Peters, D. 1989. Improved detection of potato leafroll virus in plant material and in aphids. Phytopathology 79:963-967.

27. Vunsh, R., Rosner, A., and Stein, A. 1990. The use of polymerase chain reaction (PCR) for the detection of bean yellow mosaic virus in gladiolus. Ann. Appl. Biol. 117:561-569.

28. Waterhouse, P. M., Gildow, F. E., and Johnstone, G. R. 1988. The luteovirus group. CMI/AAB Descriptions of Plant Viruses no 339. 